\title{
Spatial differentiation of airborne arboreal pollen in Lublin (Poland)
}

\author{
Krystyna Piotrowska-Weryszko ${ }^{1 *}$, Elżbieta Weryszko-Chmielewska² \\ ${ }^{1}$ Department of General Ecology, University of Life Sciences in Lublin, Leszczyńskiego 58, 20-950 Lublin, Poland \\ ${ }^{2}$ Department of Botany, University of Life Sciences in Lublin, Akademicka 15, 20-950 Lublin, Poland
}

\begin{abstract}
The study compared the occurrence of airborne pollen of 7 arboreal taxa (Corylus, Alnus, Cupressaceae/Taxaceae, Populus, Fraxinus, Betula and Carpinus) during the period 2007-2009 from two sites in Lublin city, SE Poland. The sites differed in the character of building development and surrounding vegetation. Pollen monitoring was conducted by the volumetric method using two Hirst-type samplers. Daily and intradiurnal pollen counts were determined. For all the taxa, Spearman's test revealed statistically significant positive correlations between daily pollen fluctuations at two sites. Nevertheless, the Mann-Whitney U-test showed differences for Cupressaceae/Taxaceae, Fraxinus, Populus and Corylus between sites. The intradiurnal pattern of pollen concentration was characterized by high variation. Cupressaceae/Taxaceae and Populus, clearly differed in hourly pollen concentrations at both sites. Moreover, in the case of Betula and Alnus it was shown that a part of pollen recorded in Lublin can originate from long-distance transport. High pollen concentrations can be expected at different hours of the day. The lowest average pollen concentrations at both sites were found during morning hours at 5 and 6 a.m. Based on the obtained results, it can be concluded that data from a single pollen-sampling device are not representative of some taxa in the particular districts of the city. Average data obtained from at least two pollen samplers could provide optimum results.
\end{abstract}

Keywords: aerobiology; pollen counts; daily variations; intradiurnal patterns; two sites

\section{Introduction}

Trees positively affect the quality of life in urban areas. They are important producers of organic matter and oxygen. Tree crowns muffle noise, restrain the wind, and capture air pollutants [1]. Woody plants have a beneficial effect on human mental and physical health [2]. Nevertheless, some of them can pose a serious threat to public health due to the allergenic properties of their pollen grains $[3,4]$. No other plant part contains such strong allergens as pollen grains. Pollen allergens cause allergy symptoms in an ever increasing number of people [5]. Therefore, systematic estimation of airborne pollen concentrations is of essential importance. Pollen monitoring results are a reflection of the type of vegetation occurring near pollen sampling sites $[6,7]$. Meteorological conditions, topography, and the type of land development also affect variations in airborne pollen concentrations [8-10].

In an urban environment, trees are an important source of pollen emissions, since they release huge amounts of pollen grains into the atmosphere. In total, one Alnus glutinosa Gaertn. inflorescence can produce 19548000 pollen grains

*Corresponding author. Email: krystyna.piotrowska@up.lublin.pl

Handling Editor: Agnieszka Grinn-Gofroń
[11], while Betula pendula Roth 10044000 grains [12]. Urban areas with different land use and woody vegetation vary in terms of the quantity and quality of airborn pollen. There are differences observed of the internal and external pollen grains structure (e.g., deformations, shrinkage, cracking). Phenological stages can occur at different times in individuals belonging to the same species but found in different sites. Pollen release and dispersal depend on microclimatic conditions prevailing in a given area. According to Emberlin and Norris-Hill [13], pollen deposition patterns are different in the centre of cities than in their outskirts. The urban microclimate and increasing turbulence caused by urban development have a significant effect on pollen dispersal. High buildings, often found in the city centre, limit the dispersal of aeroplankton and for this reason high pollen concentrations can persist there longer than in open areas. Mean air temperature increases by $0.5-1^{\circ} \mathrm{C}$ in densely built-up areas of the city [14]. The urban heat island, which is created by, among others, the warming effect of urban development and numerous additional sources of heat emissions in the city, also affects significantly the dispersal of pollen grains. Higher temperatures in city centres can, among others, prolong the plant growth [15-17].

In individual plant species, diurnal fluctuations of pollen concentrations depend on the genetically determined pattern of pollen release from anthers, but this pattern is modified by 
weather conditions [18]. Pollen from long-distance transport can have an effect on increasing daily pollen concentrations [8]. The diurnal distribution of pollen concentrations is clearly modified by rainfall. Rain, in particular persistent rain, effectively clears the air of particles suspended in it, including pollen grains, but at the beginning of a rainfall event there is a substantial increase in pollen concentration. The number of airborne pollen grains significantly decreases only after several hours when they are washed out of the air. The main factors that modify the diurnal patterns the most are rainfall and wind speed. Therefore, data from rainless days are used to analyze the intradiurnal patterns of pollen concentrations $[8,19]$.

The present study defined the occurrence of airborne arboreal pollen, which may cause pollinosis. In Poland pollen grains of arboreal plants are present in the atmosphere during the spring period. Among them, Betula pollen, which contains strong allergens and occurs at very high concentrations, is of the greatest importance from the point of view of allergology [20,21]. The aim of this study was to verify whether differences between pollen monitoring data from two sampling sites with different types of urban development and local vegetation, located in different district of the city, are significant. Seasonal, daily and intradiurnal pollen concentrations of selected arboreal taxa, frequently found in the area of Lublin and in other regions of Poland, were compared.

\section{Material and methods}

The study of airborne pollen concentrations of 7 taxa (Corylus, Alnus, Cupressaceae/Taxaceae, Populus, Fraxinus, Betula and Carpinus) was conducted in two districts of Lublin, SE Poland, during the period 2007-2009. The distance between sampling sites was slightly more than $2 \mathrm{~km}$. Pollen monitoring was carried out by the volumetric method according to the recommendations of the International Association for Aerobiology [22]. Two Hirst-type samplers were used (Lanzoni VPPS 2000).

Site 1 was located in the city centre in Akademicka Street ( $51^{\circ} 14^{\prime} 37^{\prime \prime} \mathrm{N}, 22^{\circ} 32^{\prime} 25^{\prime \prime} \mathrm{E} ; 197 \mathrm{~m}$ above sea level). Its immediate vicinity is a quite densely built-up area with several storey buildings. The plants from the following genera: Betula, Quercus, Salix, Aesculus, Populus, and Larix grow nearby the sampling site. A bit further away, there is a cemetery with a predominance of Cupressaceae and Taxaceae as well as the University Park and the Saxon Garden (Ogród Saski), in which Populus dominates. Moreover, trees and shrubs of the following genera can be found there: Quercus, Acer, Fagus, Carpinus, Picea, Cupressaceae, Taxaceae and Pinus. Tree plantings along nearby streets include mainly Populus, Tilia, and Fraxinus.

Site 2 was located in a western district of Lublin, outside the city centre in Skromna Street $\left(51^{\circ} 15^{\prime} 11^{\prime \prime} \mathrm{N}, 22^{\circ} 30^{\prime} 17^{\prime \prime}\right.$ E; $189 \mathrm{~m}$ above sea level). Low buildings are predominant in this neighborhood: single-family houses with gardens as well as service and retail facilities. Single individuals of Carpinus, Betula, Thuja, and Populus (female plants) are found in the immediate vicinity. Trees growing in home gardens, allotment gardens, the Botanical Garden, and the
Open-Air Village Museum, located in the Czechówka River valley, are also a potential source of pollen (Corylus, Alnus, Tilia, Populus, and Betula predominate).

The pollen traps at site 1 and site 2 were installed at a height of $18 \mathrm{~m}$ and $15 \mathrm{~m}$ above ground level, respectively. Silicone fluid was used as the adhesive substance and glycerine jelly stained as the mounting number of pollen grains per cubic meter of air $\left(\mathrm{P} / \mathrm{m}^{3}\right)$. The $95 \%$ method was used to determine the start and end dates of the pollen season [23]. The start of the season was defined as the date when $2.5 \%$ of the seasonal cumulative pollen count was trapped and the end of the season when the cumulative pollen count reached $97.5 \%$. Rainless days on which the concentration was relatively high and exceeded $20 \mathrm{P} / \mathrm{m}^{3}$ were chosen to analyze the hourly pattern of occurrence of airborne pollen [8]. Intradiurnal variation of pollen concentration are expressed as percentage of the total daily count.

The order of the studied taxa in the tables and figures follows the sequence of plant flowering phenology. The following pollen season parameters were analyzed: start, end, peak value (daily maximum pollen concentration), peak date (date of daily maximum pollen concentration), mean daily concentrations and SPI (seasonal pollen index - the sum of pollen grains during the given season).

The distribution of data was tested using the ShapiroWilk test. Because the data did not fit a normal distribution curve, Spearman's correlation test was used for testing the degree of similarity of fluctuations of pollen counts [24]. The Mann-Whitney $U$-test was used to compare average daily pollen concentrations at both sites [25]. Cluster analysis (the $k$-means method) was used for the classification of the diurnal pattern of variation in pollen concentration. This method is based on automatic grouping of similar objects. All statistical analyses were performed using STATISTICA ver. 8.

\section{Results}

The comparison of the average daily concentrations of airborne pollen of the studied taxa at both sites in Lublin for the three-year study period is shown in Fig. 1. The curves representing the occurrence of airborne pollen grains of Corylus, Alnus, Betula and Carpinus were very similar at both sites. The pollen concentrations had in many days similar values and showed a decreasing or increasing trend over the same period of time (Fig. 1). However, distinct differences in the values of daily pollen concentrations were recorded for Cupressaceae/Taxaceae, Populus, and Fraxinus. In spite of similar increasing or decreasing trends, much higher pollen concentrations of the above-mentioned last three taxa were observed at site 1 , in particular in the second half of the pollen season (Fig. 1).

During pollen monitoring carried out at both sites, it was found that pollen season started earlier at site 2 than at site 1 for two taxa - Cupressaceae/Taxaceae by $1-5$ days, and Fraxinus by $5-10$ days (Tab. 1, Fig. 1). Generally, for these taxa slightly larger differences were observed for the end dates of the season than for its onset. The start and end dates of the Alnus and Carpinus pollen seasons were characterized by the lowest variation between both sites. 

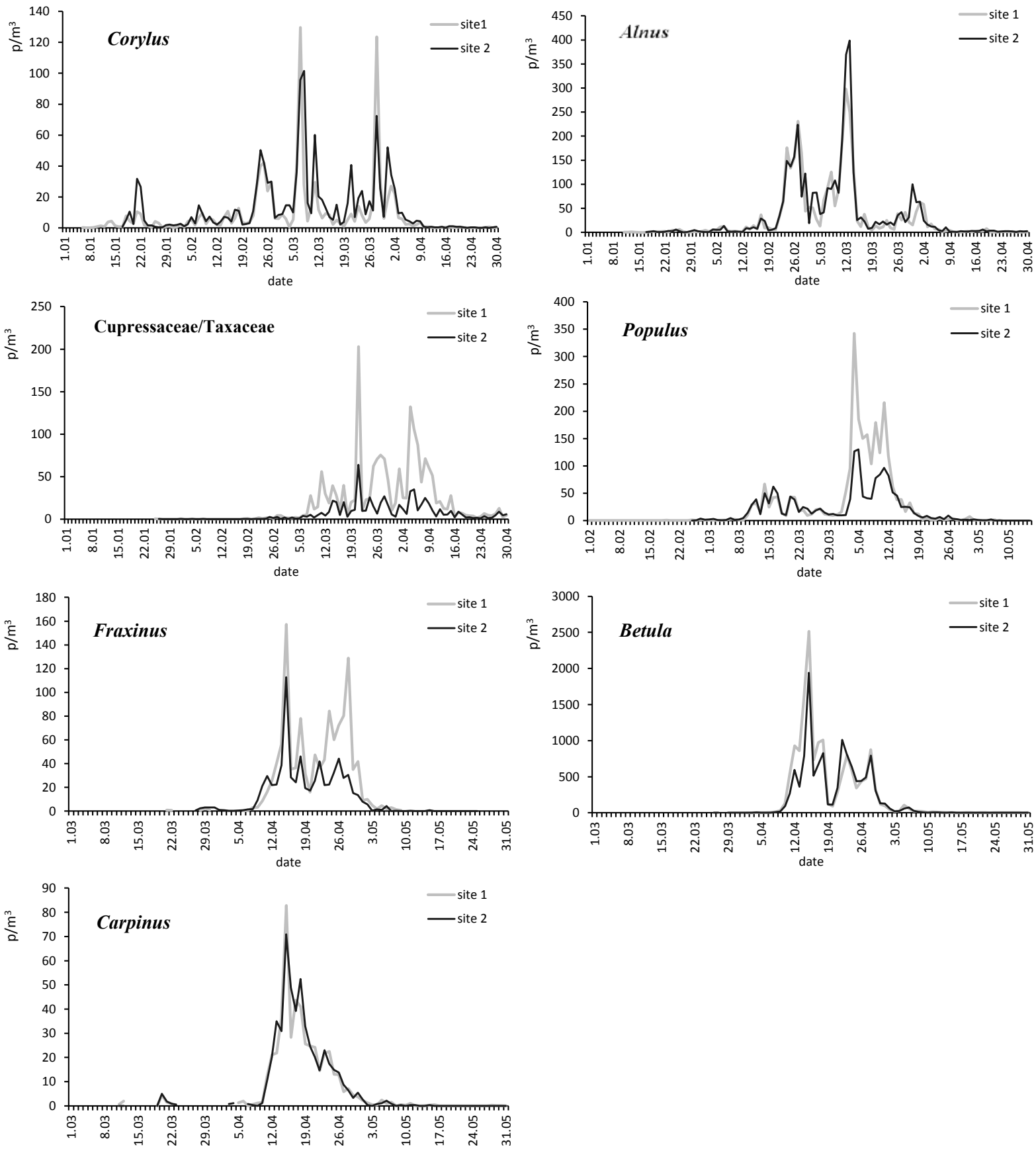

Fig. 1 Daily pollen concentrations of seven arboreal taxa at two sites in Lublin, SE Poland (average from 2007-2009).

The values of maximum pollen concentration varied the most for Cupressaceae/Taxaceae, Populus, and Fraxinus. Over the 3-year study period, higher peak values for these taxa were recorded at site 1 than at site 2 . The maximum Betula pollen concentrations were higher in two years of the study (2007 and 2008) at site 1, whereas in 2009 the peak value was slightly higher at site 2 (Tab. 1 ). The lowest differences in the peak values and SPI between sites were observed for Carpinus. The maximum pollen concentrations of most of the taxa occurred at the same or similar time (Tab. 1). The average for the three-year study period showed higher values of SPI at site 1 for Cupressaceae/Taxaceae, Fraxinus, Populus, and Betula, while at site 2 for Corylus. The seasonal pollen index for Alnus was higher at site 2 in two years of the study (2007 and 2009), whereas in 2008 the value of SPI at both sites was similar. Also, the SPI for Populus was lower at site 2 in 2009 (Fig. 2).

For all the taxa, Spearman's test revealed statistically significant positive correlations between daily pollen fluctuations at two sites. (Tab. 2). The strongest correlation was found for Betula, while the weakest one for Cupressaceae/ Taxaceae. Based on the Mann-Whitney $U$-test, it was found that the daily pollen concentrations of Alnus, Betula and Carpinus did not differ between sites over three years of the study (Tab. 3 ). At site 1, significantly higher pollen concentrations of Cupressaceae/Taxaceae and Fraxinus were 
Tab. 1 Characteristics of the pollen season of the selected arboreal taxa at two sites in Lublin city, SE Poland.

\begin{tabular}{|c|c|c|c|c|c|c|c|}
\hline \multirow[b]{2}{*}{ Taxon } & \multirow[b]{2}{*}{ Year } & \multicolumn{2}{|c|}{$\begin{array}{l}\text { Dates of pollen season } \\
\text { (start and end) }\end{array}$} & \multicolumn{2}{|c|}{$\begin{array}{l}\text { Maximum daily pollen } \\
\text { concentration }\left(\mathrm{P} / \mathrm{m}^{3}\right)\end{array}$} & \multicolumn{2}{|c|}{$\begin{array}{c}\text { Date of maximum daily } \\
\text { pollen concentration }\end{array}$} \\
\hline & & site 1 & site 2 & site 1 & site 2 & site 1 & site 2 \\
\hline \multirow[t]{3}{*}{ Corylus } & 2007 & $14.01-20.03$ & $17.01-22.03$ & 388 & 304 & 7.03 & 8.03 \\
\hline & 2008 & $4.02-30.03$ & $4.02-14.03$ & 104 & 127 & 24.02 & 24.02 \\
\hline & 2009 & $8.02-9.04$ & $8.02-9.04$ & 368 & 217 & 28.03 & 28.03 \\
\hline \multirow[t]{3}{*}{ Alnus } & 2007 & $1.03-27.03$ & $28.02-27.03$ & 829 & 1117 & 12.03 & 13.03 \\
\hline & 2008 & $6.02-18.03$ & $7.02-18.03$ & 691 & 670 & 27.02 & 27.02 \\
\hline & 2009 & $10.03-30.04$ & $10.03-27.04$ & 176 & 291 & 1.04 & 31.03 \\
\hline \multirow{3}{*}{$\begin{array}{l}\text { Cupressaceae/ } \\
\text { Taxaceae }\end{array}$} & 2007 & $12.03-11.05$ & $8.03-20.05$ & 605 & 191 & 21.03 & 21.03 \\
\hline & 2008 & $27.02-12.05$ & $25.02-8.05$ & 142 & 23 & 11.03 & 10.04 \\
\hline & 2009 & $29.03-10.05$ & $28.03-10.05$ & 326 & 105 & 4.04 & 5.04 \\
\hline \multirow[t]{3}{*}{ Populus } & 2007 & $13.03-16.04$ & $11.03-21.04$ & 720 & 185 & 4.04 & 16.03 \\
\hline & 2008 & $7.03-17.04$ & $2.03-12.04$ & 273 & 73 & 11.04 & 10.04 \\
\hline & 2009 & $4.04-19.04$ & $3.04-23.04$ & 405 & 382 & 9.04 & 5.04 \\
\hline \multirow[t]{3}{*}{ Fraxinus } & 2007 & $13.04-4.05$ & $8.04-5.05$ & 193 & 92 & 28.04 & 26.04 \\
\hline & 2008 & $10.04-30.04$ & $31.03-26.04$ & 454 & 312 & 15.04 & 15.04 \\
\hline & 2009 & $16.04-2.05$ & $9.04-2.05$ & 135 & 37 & 24.04 & 30.04 \\
\hline \multirow[t]{3}{*}{ Betula } & 2007 & $12.04-4.05$ & $12.04-5.05$ & 2762 & 1916 & 15.04 & 18.04 \\
\hline & 2008 & $11.04-5.05$ & $11.04-29.04$ & 4356 & 3797 & 15.04 & 15.04 \\
\hline & 2009 & $10.04-7.05$ & $13.04-3.05$ & 521 & 585 & 17.04 & 17.04 \\
\hline \multirow[t]{3}{*}{ Carpinus } & 2007 & $11.04-28.04$ & $11.04-27.04$ & 133 & 122 & 15.04 & 16.04 \\
\hline & 2008 & $10.04-5.05$ & $10.04-30.04$ & 115 & 94 & 15.04 & 15.04 \\
\hline & 2009 & $17.04-2.05$ & $15.04-30.04$ & 78 & 111 & 18.04 & 18.04 \\
\hline
\end{tabular}

recorded in two years, while for Populus in one year of the study. At site 2, significantly higher pollen concentrations of Corylus were observed in one year of the study.

The analysis of the diurnal pollen concentration revealed different pollen patterns. In the case of Corylus and Carpinus, high counts were observed between 11 and 16 hours. At both sampling sites, higher concentrations of Alnus pollen were recorded in the afternoon and in the evening hours, and of Fraxinus in the afternoon hours (14-17). The number of Cupressaceae/Taxaceae pollen grains increased earlier at site 2 than at site 1 , but it remained at a rather equal level, whereas at site 1 the highest concentrations were recorded between 14 and 15 hours. The intradiurnal concentrations of Populus pollen were characterized by an irregular pattern, while elevated concentrations were observed in different hours of a day. No one clear peak throughout 24 hours was observed for Betula (Fig. 3).

Based on $k$-means clustering analysis, we distinguished three types of curves showing the intradiurnal occurrence of pollen. The first type was characterized by several not very high peaks occurring at different times during the day, with small differences between the hours of maximum and minimum concentration, whereas the second and third types had one clear peak. The largest number of curves of diurnal variation in pollen concentration was classified as the first type and included the following data: from both sites for Alnus, Fraxinus and Betula, from site 1 for Populus, while from site 2 for Cupressaceae/Taxaceae. In the second type, the maximum hourly concentrations occurred between 11 and 16 hours. The data for Corylus and Carpinus from both sites as well as the data for Populus from site 2 were included in this type. Only the diurnal counts of Cupressaceae/Taxaceae pollen from site 1 were included in type three which was characterized by one clear peak in the early afternoon. The analysis of the data shows that the largest differences between sites were found in the hourly distribution of pollen for Cupressaceae/Taxaceae and Populus. Based on the average pollen concentrations of all taxa, it was found that the lowest concentrations were recorded at 5 and 6 a.m.

\section{Discussion}

Despite that the sampling sites clearly differed in the type of vegetation as well as in the type of buildings and land use, the shape of the curves representing the occurrence 

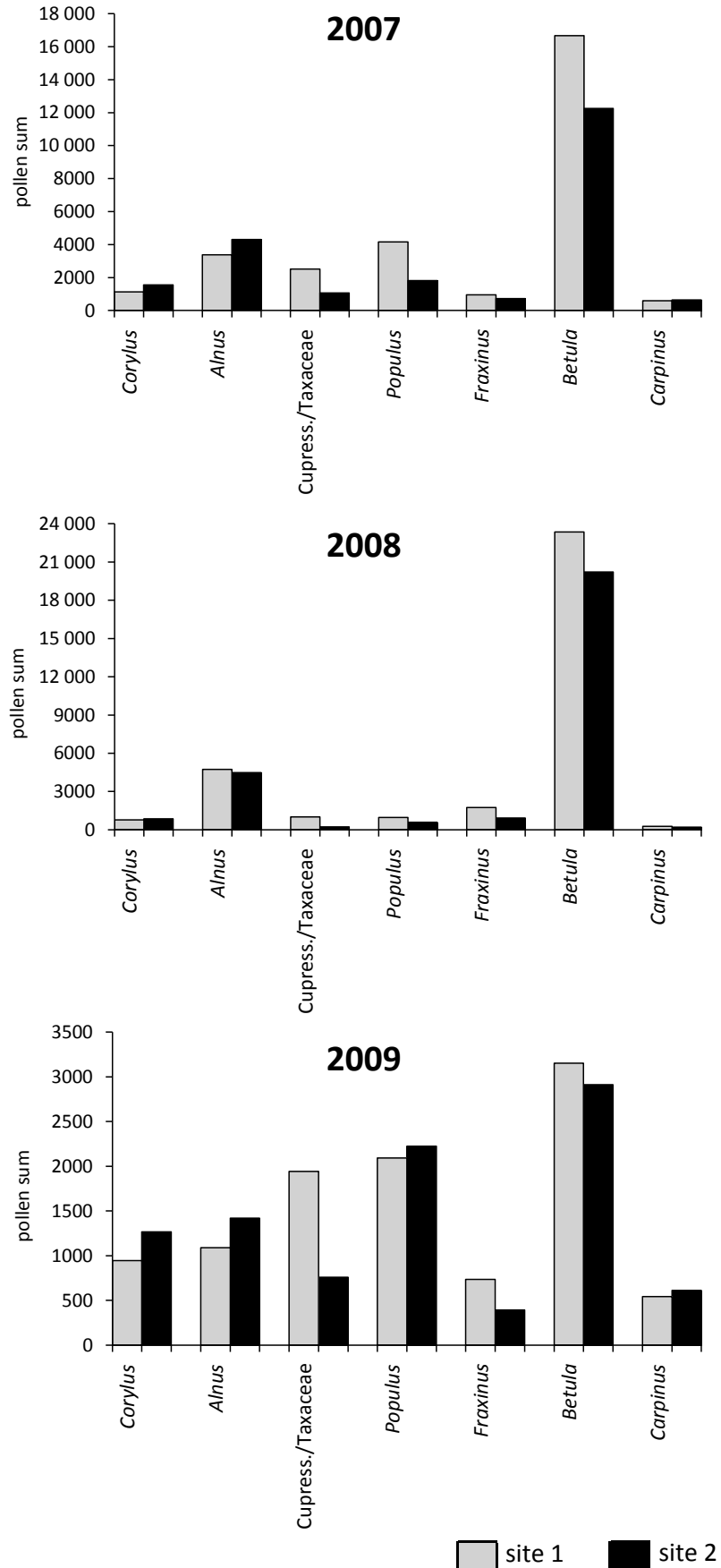

Fig. 2 Comparison seasonal pollen index of seven taxa at two sites in Lublin, SE Poland (2007-2009).

of airborne pollen grains of most of the studied taxa which were recorded at both sites in Lublin was very similar. This results from a relatively close distance between these sampling sites at which similar weather conditions prevail. According to many authors, differences in the main pollen seasons are not significant in areas characterized by similar climatic conditions [26-28]. The results of measurements of daily pollen concentrations in Lublin at both sites were significantly correlated. Other authors have also found a high positive correlation for daily pollen concentrations at sites located in different districts of a city $[7,27,29]$.
Tab. 2 Significant Spearman correlation coefficients between daily pollen concentrations at two sites in Lublin, SE Poland.

\begin{tabular}{llll}
\hline Taxon & $\mathbf{2 0 0 7}$ & $\mathbf{2 0 0 8}$ & $\mathbf{2 0 0 9}$ \\
\hline Corylus & 0.812 & 0.773 & 0.729 \\
Alnus & 0.777 & 0.845 & 0.870 \\
Cupress./Taxaceae & 0.759 & 0.574 & 0.755 \\
Populus & 0.694 & 0.744 & 0.847 \\
Fraxinus & 0.763 & 0.656 & 0.857 \\
Betula & 0.934 & 0.907 & 0.930 \\
Carpinus & 0.696 & 0.742 & 0.866 \\
\hline
\end{tabular}

$P<0.01$.

Tab. 3 Comparision of daily pollen concentrations between two sites in Lublin, SE Poland. Results of Mann-Whitney $U$-test. The values of $z$ statistic are given.

\begin{tabular}{lccc}
\hline Taxon & $\mathbf{2 0 0 7}$ & $\mathbf{2 0 0 8}$ & $\mathbf{2 0 0 9}$ \\
\hline Corylus & $-1.082 \mathrm{~ns}$ & $-2.575^{* *}$ & $-1.910 \mathrm{~ns}$ \\
Alnus & $-0.564 \mathrm{~ns}$ & $0.219 \mathrm{~ns}$ & $-1.519 \mathrm{~ns}$ \\
Cupress./Taxaceae & $2.237^{*}$ & $4.569^{* *}$ & $1.774 \mathrm{~ns}$ \\
Populus & $3.028^{* *}$ & $0.219 \mathrm{~ns}$ & $0.828 \mathrm{~ns}$ \\
Fraxinus & $1.173 \mathrm{~ns}$ & $3.440^{* *}$ & $3.162^{* *}$ \\
Betula & $0.128 \mathrm{~ns}$ & $-0.983 \mathrm{~ns}$ & $-1.566 \mathrm{~ns}$ \\
Carpinus & $-0.610 \mathrm{~ns}$ & $-0.514 \mathrm{~ns}$ & $-0.509 \mathrm{~ns}$ \\
\hline
\end{tabular}

${ }^{*} P<0.05 ;{ }^{* *} P<0.01 ;$ ns - not significant.

The research carried out in Lublin found that the start and end dates of pollen seasons of most of the plant taxa studied were similar at both sites. An exception was the Fraxinus pollen season which started earlier by $5-10$ days at site 2, which may result from the location of the ash stands at very sunny sites with lower diurnal air temperature amplitudes, characteristic of areas distant from large urban centres [30].

The variations mostly related to the peak value and SPI. The higher pollen concentrations of Cupressaceae/Taxaceae, Populus and Fraxinus at site 1 result from the close vicinity of plants belonging to the above-mentioned taxa. In turn, the higher Corylus pollen counts at site 2 can be attributable to Corylus stands located near this sampling site. However, numerous authors stress that even in closely located areas, e.g., in different districts of the same city, spatial differences in pollen concentration are recorded [7,13,31,32]. These differences are irrelevant from the point of view of allergology, since after the threshold value for the allergic reaction has been reached even large quantitative differences cause minor consequences $[7,31]$. It can be therefore assumed that 

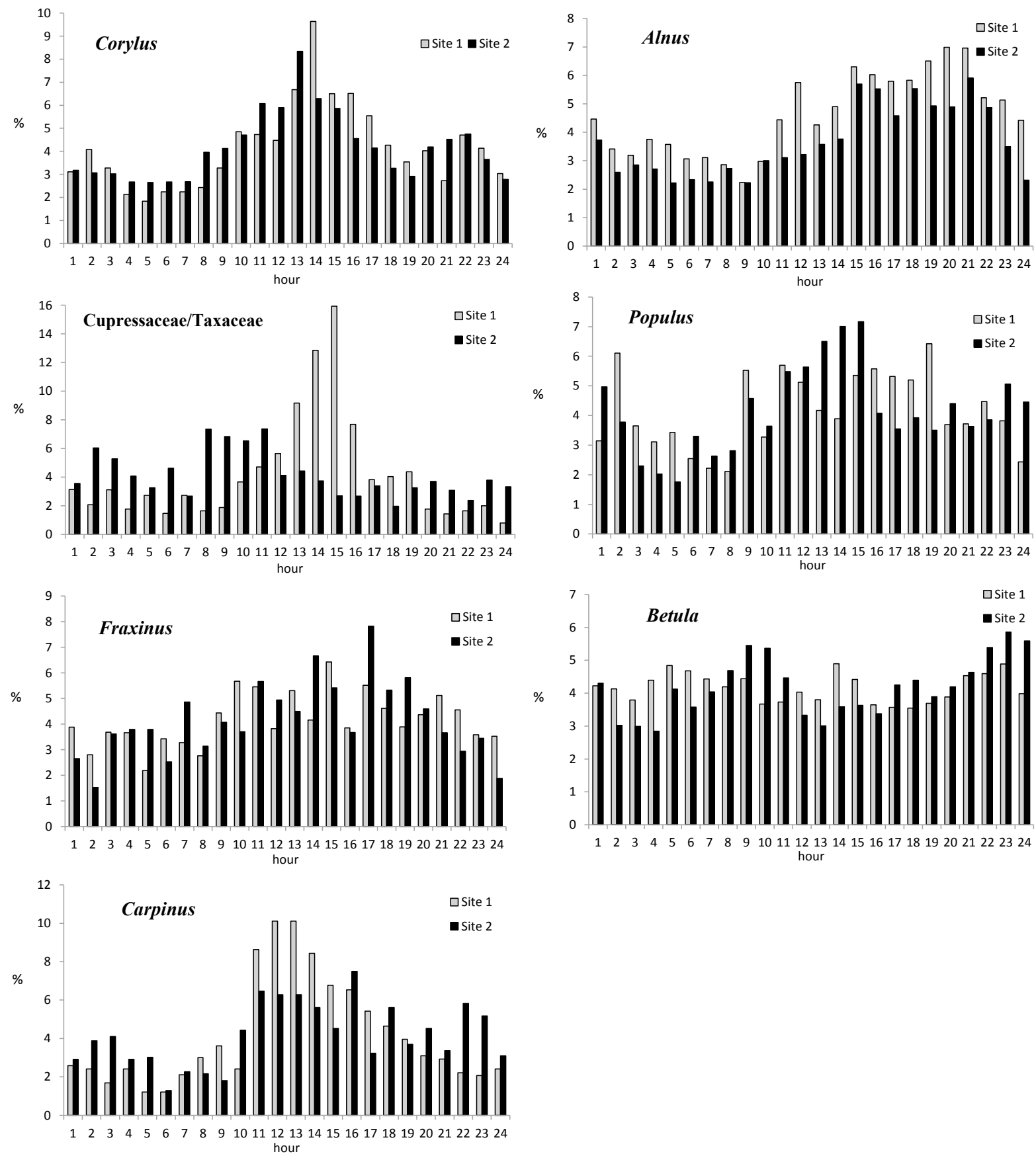

Fig. 3 Intradiurnal variation of pollen concentrations of seven arboreal taxa at two sites in Lublin, SE Poland.

data from one locality in a city are sufficient for providing pollen forecasts for allergy sufferers. Also according to Velasco-Jiménez et al. [7], data from a single volumetric sampler located in a city with a uniform topography and similar vegetation conditions are sufficient for monitoring major types of airborne pollen. According to Kasprzyk [15], the pollen spectrum and the seasonal cycle of occurrence of airborne pollen were similar in two sites differing in land development (an urban area and a rural area) and located about $10 \mathrm{~km}$ away from each other. Based on her research, the above-mentioned author found that pollen concentrations at one site could be predicted on the basis of data taken from another one.
The results for the diurnal variation of pollen concentration in Lublin for some pollen types were similar to the data found in the literature. For example, at both sites in Lublin hourly Alnus pollen concentrations in the first half of the day were much lower than during the second half. A similar pattern of the diurnal fluctuation of Alnus pollen concentrations has been found in Poznań, E Poland and Gdańsk, N Poland $[19,33]$. The curve of the diurnal variation of Cupressaceae/ Taxaceae pollen in Lublin (site 1) had one clear maximum at 2-3 p.m. The diurnal maximum for Cupressaceae/Taxaceae was observed exactly at the same time in Spain [34]. At both sites in Lublin, the birch pollen concentration showed relatively small fluctuations at particular hours of the day. 
Similar observations have been made by other authors in different cities of Poland $[9,19]$.

In the study conducted in Lublin, the lowest pollen concentration throughout 24 hours for most of the taxa studied was found at both sites during morning hours at 5 and 6 a.m. In Denmark, the lowest pollen concentration of birch pollen was found between 5 and 7 a.m. [35]. According to Cariñanos et al. [36], the lowest values of pollen concentration occurring between 5 and 7 a.m. are a consequence of the negative effect of environmental humidity.

The similarities in the diurnal variation in pollen concentrations of some taxa in Lublin and at other sampling sites, sometimes located in other countries, may indicate the genetically determined pattern of pollen release in plants. The diurnal patterns show very similar general features, regardless of the study region [19]. On the other hand, there are marked differences in the intradiurnal distribution of pollen concentration at sites with a different topography, even located at a short distance [10]. The character of building development and various urban planning solutions are also of major importance [9]. The differences in the diurnal patterns for Cupressaceae/Taxaceae and Populus at the two sites in Lublin located at a close distance from each other are evidence of the great effect of local factors. The differences in hourly pollen concentrations at both sites in Lublin probably result from different land development that creates slightly different conditions for pollen release and dispersal. The spatial distribution of buildings in the district more distant from the city centre (site 2 ) may modify the microclimatic conditions prevailing there by decreasing the diurnal temperature amplitudes and increasing relative humidity relative to the districts located closer to the city centre, which was found in an earlier study [30].

As far as the diurnal pattern of high concentrations of Betula and Alnus pollen is concerned, it should be stressed that they also occurred during evening and night hours. Because pollen grains of Betula (19-22 $\mu$ ) and Alnus (21-24 $\mu$ ) are small and light, it can be presumed that they were carried by air currents at night from distant areas as a result of long-distance transport of aeroplankton (over $10 \mathrm{~km}$ ). Many studies have shown that small pollen grains (18-19 $\mu$ ) of Ambrosia are carried for large distances due to the movement of air masses [37,38].

In the study conducted in Lublin, three types of the hourly distribution of airborne pollen concentrations were distinguished based on $k$-means clustering. This method had been earlier used to classify pollen seasons based on

\section{Acknowledgments}

Research supported by Poland's Ministry of Science and Higher Education as part of the statutory activities of the University of Life Sciences in Lublin.

\section{Authors' contributions}

The following declarations about authors' contributions to the research have been made: microscope analysis: KPW, EWC; statistical analysis: KPW; writing the manuscript: KPW, EWC.

\section{Competing interests}

EWC is a honorary editor of the Acta Agrobotanica; KPW: no competing interests. daily pollen concentrations $[39,40]$. The type in which there was no well-expressed trend was represented by the largest number. High pollen concentrations occurred both during the day and at night. Galan et al. [41] distinguished two types of the diurnal pattern of airborne pollen. The first type was characterized by small differences between maximum and minimum hourly pollen concentrations, while in the case of the second type these differences were large. The maximum pollen concentrations were also recorded at different hours in particular years. This primarily related to the taxa whose pollen was present in the air in small amounts [41].

\section{Conclusions}

Seasonal occurrence of pollen of the taxa studied at both sampling sites was to a certain extent similar with highly convergent trends of decrease and increase in daily pollen concentrations. Significant correlations between average daily concentrations at both sites for all taxa studied was evidenced. The differences between sites are mostly related to maximum concentrations and the seasonal pollen index. The disparity was mainly due to the species composition of tree plants in the vicinity of the sampling sites.

The analysis of hourly pollen concentrations of the arboreal plants studied revealed three types of curves representing the intradiurnal pattern of occurrence of airborne pollen. The type that was characterized by the absence of one peak and frequently by a quite equal pollen concentration throughout 24 hours was represented by the greatest number. The second and third types of intradiurnal variation of pollen concentration had a clear peak, in the afternoon hours. Similar results for hourly pollen concentrations at both sites were obtained for Corylus, Alnus, Fraxinus, Betula, and Carpinus. On the other hand, the other types of pollen, Cupressaceae/Taxaceae and Populus, clearly differed in hourly pollen concentrations at both sites. Moreover, in the case of Betula and Alnus it was shown that a part of pollen recorded in Lublin can originate from long-distance transport. High pollen concentrations can be expected at different hours of the day. The lowest average pollen concentrations at both sites were found during morning hours at 5 and 6 a.m.

Data from a single pollen-sampling device are not representative for some taxa in the particular districts of the city. Average data obtained from at least two pollen samplers could provide optimum results.

\section{References}

1. Reichholf JH, Steinbach G, editors. Drzewa i krzewy. Wielka encyklopedia. Warszawa: Muza SA; 1995.

2. Chiesura A. The role of urban parks for the sustainable city landscape. Landsc Urban Plan. 2004;68:129-138. http://dx.doi.org/10.1016/j. landurbplan.2003.08.003

3. Jäger S, Horak F. Allergenic pollen and pollinosis in Austria. In: D’Amato G, Spieksma FTM, Bonini S, editors. Allergenic pollen and pollinosis in Europe. Oxford: Blackwell Scientific; 1991. p. 137-140.

4. D’Amato G, Cecchi L, Bonini S, Nunes C, Annesi-Maesano I, Behrendt $\mathrm{H}$. Allergenic pollen and pollen allergy in Europe. Allergy. 2007;62:976-990. http://dx.doi.org/10.1111/j.1398-9995.2007.01393.x 
5. Pawankar R, Canonica GW, Holgate ST, Lockey RF, editors. World Allergy Organization (WAO) white book on allergy. United Kingdom: World Allergy Organization; 2011.

6. Rizzi Longo L. Anthesis and pollination of some trees in the surroundings of Trieste. Studia Geobotanica. 1990;10:147-159.

7. Velasco-Jiménez MJ, Alcázar P, Domínguez-Vilches E, Galán C. Comparative study of airborne pollen counts located in different areas of the city of Córdoba (south-western Spain). Aerobiologia. 2013;29:113-120. http://dx.doi.org/10.1007/s10453-012-9267-x

8. Berggren B, Nilsson S, Boëthius G. Diurnal variation of airborne birch pollen at some sites in Sweden. Grana. 1995;34:251-259. http://dx.doi. org/10.1080/00173139509429054

9. Kasprzyk I, Harmata K, Myszkowska D, Stach A, Stępalska D. Diurnal variation of chosen airborne pollen at five sites in Poland. Aerobiologia. 2001;17:327-345. http://dx.doi.org/10.1023/A:1013078627196

10. Garcia-Mozo H, Comtois P, Kuehne E. Aerobiological lines: the role topography as a barrier for establishing dispersal corridors. Aerobiologia. 2004;20:161-172. http://dx.doi.org/10.1023/ B:AERO.0000032953.03309.c5

11. Piotrowska K. Ecological features of flowers and the amount of pollen released in Corylus avellana (L.) and Alnus glutinosa (L.) Gaertn. Acta Agrobot. 2008;61(1):33-39. http://dx.doi.org/10.5586/aa.2008.004

12. Piotrowska K. Pollen production in selected species of anemophilous plants. Acta Agrobot. 2008;61(1):41-52. http://dx.doi.org/10.5586/ aa.2008.005

13. Emberlin J, Norris-Hill J. Spatial variation of pollen deposition in north London. Grana. 1991;30:190-195. http://dx.doi. org/10.1080/00173139109427798

14. Sudnik-Wójcikowska B. Flora miasta - chaos i przypadek czy prawidłowości w różnorodności? Kosmos. 2002;51(2):213-219.

15. Kasprzyk I. Comparative study of seasonal and intradiurnal variation of airborne herbaceous pollen in urban and rural areas. Aerobiologia. 2006;22:185-195. http://dx.doi.org/10.1007/s10453-006-9031-1

16. Mimet A, Pellissier V, Quénol H, Aguejdad R, Dubreuil V, Rozé F. Urbanisation induces early flowering: evidence from Platanus acerifolia and Prunus cerasus. Int J Biometeorol. 2009;53:287-298. http://dx.doi. org/10.1007/s00484-009-0214-7

17. Rodríguez-Rajo FJ, Fdez-Sevilla D, Stach A, Jato V. Assessment between pollen seasons in areas with different urbanization level related to local vegetation sources and differences in allergen exposure. Aerobiologia. 2010;26:1-14. http://dx.doi.org/10.1007/s10453-009-9138-2

18. Käpylä M. Diurnal variation of non-arboreal pollen in the air in Finland. Grana. 1981;20:55-59. http://dx.doi.org/10.1080/00173138109436737

19. Latałowa M, Uruska A, Pędziszewska A, Góra M, Dawidowska A. Diurnal patterns of airborne pollen concentration of selected tree and herb taxa in Gdańsk (northern Poland). Grana. 2005;44:192-201. http://dx.doi.org/10.1080/00173130500219692

20. Spieksma FThM. Pollinosis in Europe: new observations and developments. Rev Palaeobot Palynol. 1990;64:35-40. http://dx.doi. org/10.1016/0034-6667(90)90114-X

21. Piotrowska K, Kubik-Komar A. The effect of meteorological factors on airborne Betula pollen concentrations in Lublin (Poland). Aerobiologia. 2012;28:467-479. http://dx.doi.org/10.1007/s10453-012-9249-Z

22. Mandrioli P, Comtois P, Dominguez VE, Galan C, Syzdek L, Isard S. Sampling: principles and techniques. In: Mandrioli P, Comtois P, Levizzani V, editors. Methods in aerobiology. Bologna: Pitagora Editrice; 1998. p. 47-112.

23. Andersen TB. A model to predict the beginning of the pollen season. Grana. 1991;30:269-275. http://dx.doi. org/10.1080/00173139109427810

24. Trigo Del Mar M, Toro FJ, Recio M, Cabezudo B. A statistical approach to comparing the results from different aerobiological stations. Grana. 2000;39:252-258. http://dx.doi.org/10.1080/00173130052017299

25. Majkowska-Wojciechowska B, Balwierz Z, Pełka J, Jarzębska M, Kowalski ML. Porównanie dynamiki opadu pyłkowego w środowisku miejskim i wiejskim centralnej Polski. Alergia Astma Immunoogia. 2005;10(3):139-147.

26. Fornaciari M, Bricchi E, Frenguelli G, Romano B. The results of 2-year pollen monitoring of an urban network in Perugia, central Italy. Aerobiologia. 1996;12:219-227. http://dx.doi.org/10.1007/BF02446278

27. Gottardini E, Cristofolini F. Spring airborne pollen data in two sites in Trentino (northen Italy): a comparison with meteorological data. Aerobiologia. 1997;13:199-204. http://dx.doi.org/10.1007/BF02694508

28. Kasprzyk I. Ziarna pyłku traw w powietrzu Rzeszowa i okolic. Ann UMCS Sec EEE. 2002;10:123-129.

29. Fernández-Rodríguez S, Tormo-Molina R, Maya-Manzano JM, Silva-Palacios I, Gonzalo-Garijo A. Comparative study of the effect of distance on the daily and hourly pollen counts in a city in the south-western Iberian Peninsula. Aerobiologia. 2014;30:173-187. http://dx.doi.org/10.1007/s10453-013-9316-0

30. Stulgis G. Zróżnicowanie warunków klimatycznych na terenie zabudowy jednorodzinnej w małych miasteczkach. Człowiek i Środowisko. 1993;17(4):413-423.

31. Arroba D, Guido MA, Minale P, Montanari C, Placereani S, Pracilio $\mathrm{S}$, et al. Airborne pollen in Genoa (NW-Italy): a comparison between two pollen-sampling stations. Aerobiologia. 2000;16:233-243. http:// dx.doi.org/10.1023/A:1007674620285

32. Piotrowska K. Wpływ lokalnej roślinności na zróżnicowanie zawartości pyłku w powietrzu dwóch dzielnic Lublina. Ann UMCS Sec EEE. 2003;12:75-85.

33. Stach A. Dobowe wahania pyłku wybranych taksonów alergogennych w powietrzu nad Poznaniem w 1996 roku. In: Conference proceedings "Biologia kwitnienia, nektarowania i zapylania roślin"; 1997 Nov 13-14; Lublin, Poland. Lublin: Agricultural Academy in Lublin; 1997. p. 197-203.

34. Trigo MM, Recio M, Toro FJ, Cabezudo B. Intradiurnal fluctuations in airborne pollen in Malaga (S. Spain): a quantitative method. Grana. 1997;36:39-43. http://dx.doi.org/10.1080/00173139709362588

35. Mahura A, Baklanov A, Korsholm U. Parameterization of the birch pollen diurnal cycle. Aerobiologia. 2009;25:203-208. http://dx.doi. org/10.1007/s10453-009-9125-7

36. Cariñanos P, Galan C, Alcazar P, Dominguez E. Diurnal variation of biological and non-biological particles in the atmosphere of Córdoba, Spain. Aerobiologia. 1999;15:177-182. http://dx.doi. org/10.1023/A:1007590023585

37. Smith M, Skjøth CA, Myszkowska D, Uruska A, Puc M, Stach A, et al. Long-range transport of Ambrosia pollen to Poland. Agric For Meteorol. 2008;148:1402-1411. http://dx.doi.org/10.1016/j. agrformet.2008.04.005

38. Piotrowska-Weryszko K, Weryszko-Chmielewska E, Voloshchuk K, Sulborska A, Kalinovych N, Vorobets N. Ragweed (Ambrosia L.) pollen in aeroplankton of Lublin (Poland) and Lviv (Ukraine). Acta Agrobot. 2013;66(3):3-10. http://dx.doi.org/10.5586/aa.2013.032

39. Dąbrowska-Zapart K. Types of hazel (Corylus spp.) and alder (Alnus spp.) pollen seasons in Sosnowiec 1997-2007 (Poland). Acta Agrobot. 2010;63(2):75-83. http://dx.doi.org/10.5586/aa.2010.035

40. Malkiewicz M, Klaczak K, Drzeniecka-Osiadacz A, Krynicka J, Migała $\mathrm{K}$. Types of Artemisia pollen season depending on the weather conditions in Wrocław (Poland), 2002-2011. Aerobiologia. 2014;30:13-23. http://dx.doi.org/10.1007/s10453-013-9304-4

41. Galán C, Tormo R, Cuevas J, Infante F, Domínguez E. Theoretical daily variation patterns of airborne pollen in the south-west of Spain. Grana. 1991;30:201-209. http://dx.doi.org/10.1080/00173139109427800

\section{Przestrzenne zróżnicowanie stężenia pyłku drzew w powietrzu Lublina (Polska)}

\section{Streszczenie}

$\mathrm{W}$ pracy porównywano dane $\mathrm{z}$ monitoringu pyłkowego prowadzonego w Lublinie na dwóch stanowiskach, które różniły się charakterem zabudowy i lokalną roślinnością. Analizowano występowanie w powietrzu pyłku 7 
taksonów roślin drzewiastych (Corylus, Alnus, Cupressaceae/Taxaceae, Populus, Fraxinus, Betula i Carpinus) w latach 2007-2009. Badania prowadzono metodą wolumetryczną z wykorzystaniem aparatów typu Hirsta. Określano dobowe i godzinowe stężenia pyłku w powietrzu. Analiza testu Spearmana dla wszystkich badanych taksonów wykazała istotną pozytywną korelację między dobowymi koncentracjami pyłku rejestrowanymi na dwóch stanowiskach. Na podstawie testu U Mann-Whitney’a stwierdzono istotne różnice między stanowiskami dla stężeń pyłku Cupressaceae/ Taxaceae, Fraxinus, Populus i Corylus. Godzinowa rytmika stężenia pyłku charakteryzowała się dużą zmiennością. Cupressaceae/Taxaceae i Populus, wyraźnie różniły się pod względem godzinowych koncentracji pyłku na obu stanowiskach. Ponadto w przypadku Betula i Alnus wykazano, że cześć rejestrowanego w Lublinie pyłku może pochodzić z dalekiego transportu. Wysokich stężeń pyłku można spodziewać się w różnych godzinach doby. Najniższe średnie stężenia pyłku na obu stanowiskach stwierdzono w godzinach porannych o 5.00 i 6.00 . Na podstawie uzyskanych wyników można przyjąć, że dane pochodzące $\mathrm{z}$ jednego punktu pomiarowego nie są reprezentatywne dla niektórych taksonów w poszczególnych częściach miasta. Optimum wyników mogłyby zapewnić średnie dane pochodzące $\mathrm{z}$ co najmniej dwóch aparatów pomiarowych umieszczonych w różnych dzielnicach. 